\title{
Anticancer activities of plant extracts of gymnacranthera farquhariana (hook. f. \& thomson) warb., myristica fatua houtt. var. magnifica (beddome) sinclair and samadera indica gaertner
}

\begin{abstract}
The present study was carried out to evaluate the anticancer properties of the extracts of leaves, bark and fruits of Gymnacranthera farquhariana and Myristica fatua var. magnifica and Samadera indica found in the forests of the Western Ghats of Karnataka, India. The aqueous and methanolic extracts were obtained through soxhlation. The extracts are used for cytotoxicity studies using MTT assay with Cell line HL-60. The percentage yield varies in all the three plants in both the solvent systems. In all the plants, the leaves yielded higher methanolic extract, as well as seeds of G. farquhariana and M. fatua var. magnifica, while the bark and fruits of $S$. indica resulted in higher yield in aqueous system. A maximum viability of $85.4 \%$ was observed with methanolic seed extract, while a minimum of $44.6 \%$ with aqueous leaf extract of Samadera indica. However, there is a good inhibition percentages with aqueous and methanolic extracts of plant parts used in the present investigation. The results of the present findings strengthen the potential of the selected plants as a resource for the discovery of novel anticancer agents. Further studies required to isolate the active principle and experiments with few more cell lines and animal model.
\end{abstract}

Keywords: anticancer activity, aqueous extract, gymnacranthera farquhariana, hl-60 cell line, methanolic extract, myristica fatua var. magnifica, samadera indica
Volume 6 Issue 5 - 2017

Rama Bhat $\mathrm{P}$

Department of Biotechnology, Alva's College, India

Correspondence: Rama Bhat P, Post Graduate Dept of Biotechnology, Alva's College, Moodbidri- 574 227, Karnataka, India,Tel +91948022839I, Email bhat_pr@rediffmail.com

Received: May 04, 2017 | Published: June 01, 2017

\section{Introduction}

Cancer is one of the most life-threatening diseases, with more than 100 different types occurring due to some molecular changes within the cell. It is the third leading cause of death worldwide following cardiovascular and infectious diseases. There are 10.9million new cases, 6.7 million deaths, and 24.6 million persons alive with cancer. It is estimated that $12.5 \%$ of the population dies due to cancer (WHO, 2004). The disease is widely prevalent, and in the West, almost a third of the population develops cancer at some point of time during their life. Although the mortality due to cancer is high, many advances have been made both in terms of treatment and understanding the biology of the disease at the molecular level. ${ }^{2}$ Accumulation of toxins through carcinogenic food like fast food, colas, habits like smoking, drinking, paan chewing, stressful lifestyle, toxic medicines and environmental pollution lowers immunity causing cancer. Conventional therapies cause serious side effects and, at best, merely extend the patient's lifespan by a few years. Better cancer treatments with milder side effects are desperately needed. Thus, there is urgent need to utilize alternative concepts or approaches to the prevention of cancer. ${ }^{3}$ Due to lack of effective drugs, cost of chemotherapeutic agents, and the side effects of anticancer drugs, cancer can be a cause of death. Therefore, efforts are still being made to search for effective naturally occurring anticarcinogens that would prevent, slow, or reverse cancer development. Medicinal plants have a special place in the management of cancer. It is estimated that plant-derived compounds in one or the other way constitute more than $50 \%$ of anticancer agents. ${ }^{4,5}$ Numerous cancer research studies have been conducted using traditional medicinal plants in an effort to discover new therapeutic agents that lack the toxic side effects associated with the present chemotherapeutic agents.

Medicinal plants have been used to cure disease and maintain health from time memorial. However, the search for bioactive compounds in these plants has intensified for the past decades. However, natural therapies, such as the use of the plants or plant derived natural products are being beneficial to combat cancer. Secondary metabolites of plants are an alternative to chemically synthesized products and microbially originated antibiotics. Screening of plants used in folklore and ethnomedicine for the cure of infectious diseases is considered as a suitable strategy as those plants are known to possess medicinal properties which are safe. ${ }^{6}$ The increasing failure of chemotherapeutic and antibiotic resistance exhibited by pathogenic microbial injections lead to the screening of several medicinal plants for their potential antimicrobial activity. ${ }^{7}$ Natural antioxidants from plants have been shown to increase the antioxidant capacity of the plasma ${ }^{8}$ while, synthetic antioxidants are reported to have toxic and carcinogenic effects in animal models. ${ }^{9}$ It has been estimated that about $80-85 \%$ of global population rely on traditional medicines for their primarily health care needs and it is assumed that a major part of traditional therapy involves the use of plant extracts or their active principles. ${ }^{10}$

Samadera indica Gaertner belongs to the family Simaroubaceae, used by folklore practitioners and tribal people for various disease treatments. All parts of the plant contain the glucoside samaderin, a bitter substance along with terpenoids and flavonoids which exerts medicinal properties against various disorders and diseases. The bark 
is used in the treatment of fevers; the juice of the pounded bark is considered a cure for skin diseases; after maceration, or in decoction, the bark and wood are used as a febrifuge, tonic, stomachic and emmenagogue. A decoction of the leaves is taken to relieve cough; the leaves are bruised and then applied externally as a treatment for erysipelas; the macerated leaves, mixed with coconut oil, are used to kill head lice. The seeds used in the treatment of bilious fevers and are commonly applied as an emetic and purgative. The oil from the seeds is applied externally on rheumatic joints, and used as a liniment on bruises. The plant is distributed in Africa - Madagascar, through the Indian Ocean to the Indian subcontinent, Myanmar, through South East Asia to Papua New Guinea and the Solomon Islands. In India parts of Kerala, Karnataka and Maharashtra usually rather rare, but locally common in tidal swamp forest or periodically inundated forest. The plant has different vernacular names Niepa bark tree (English), Lokhandi (Hindi), Kaduhonge (Kannada), Karinjotta/ Karingota (Malayalam) and Guccha karanjah (Sanskrit).

Myristicaceae is one of the important families of flowering plants comprising 19 genera and 400 species widely distributed, among which the genus Myristica comprises 80 species (Mabberley, 1987). M. fatua var. magnifica is a dominant species found in Myristica swamp forest. Due to anthropological activity and conversion of this habitat to cash crop plantations and teak forests, the fresh water swamp now dwindled to small fractions in Karnataka and Kerala where altogether three localities where fringes can be seen. ${ }^{11}$ It is endemic, rare and threatened. It is commonly known as Choora pannu (Tamil), Dodda yele Ramapatre (Kannada) and Kotthapanu or Kothapayin or Churapayin (Malayalam). It is distributed as remnant patches in Southern Western Ghats: Kerala- Kollam, Kozhikode, Thiruvananthapuram; KarnatakaUttara Kannada, Shimoga; Tamil Nadu- Tirunelveli. The other species of this family possess antimicrobial and antioxidant activity. There is one report on the use of aril covering the seed of this plant used as dyeing in Dakshina Kannada (Anonymous, 1962). There are recent reports on antimicrobial and antioxidant activities of this plant. ${ }^{11,12}$ But due to habitat exploitation of plant narrowed the species the RED LIST OF PLANTS, which need special method of conservation strategy. Conservation of habitat as well as fresh water ecosystemthe Myristica swamp needs first rank of attention in the Biodiversity Conservation Acts.

Gymnacranthera farquhariana distributed in Myristica swamps of Gersoppa, Shimoga district of Karnataka as well as in other swamp forests of Uttara Kannada and Dakshina Kannada districts. This species is co-dominant tree of the Myristica swamp vegetation. The species is exclusively associated with swampy conditions and habitat destruction seems to be the major threat. The species name $G$. canarica alludes to the North Karnataka region called Kanara. It is an evergreen tree. The use of plant extracts and phytochemical, both with known antimicrobial properties are of great significance to therapeutic treatments. Extracts of plants were used for the treatment of various diseases and this forms the basis for all Indian system of medicines. However, this area is not much developed when compared to modern system of medicines, mainly because of the lack of scientific documentation in this field. Some of the genera of this family possess antimicrobial and antioxidant activity which were scientifically proved. The seeds contain fat which were used for making candles in earlier days but other uses have not been recorded (Anonymous, 1962). There is one report on phytochemical properties, antimicrobial and antioxidant activities of seeds this plant. ${ }^{13,14}$ The objectives of the present investigation is to test the plant extracts of Myristica fatua var. magnifica, Gymnacranthera farquhariana and Samadera indica for anticancer activity using $\mathrm{HL}-60$ cell line.

\section{Materials and methods}

\section{Collection of plant sample}

Samadera indica leaves bark and fruit were collected from the forests of Kasaragod district, Kerala during the month of March - May 2016. The seeds and leaves of Gymnacranthera farquhariana and M. fatua var. magnifica were collected from Kathal kane evergreen swamp forests of Shimoga district, near Jog Falls, Karnataka during August - September 2016. The leaf, bark and fruits were allowed to shade dry for a week. These were then kept in hot air oven at $60^{\circ} \mathrm{C}$ for 24-48hours until it was dried completely. These were then coarsely powdered and stored in a closed container for further use.

\section{Preparation of aqueous and methanolic extracts}

The coarse powder of the seed, bark and leaves (40 g) was extracted separately by soxhlation process. The mass thus obtained was extracted for 1 hour with $150 \mathrm{ml}$ of distilled water. This was followed by the distillation process. The extract thus obtained was dried in water bath at $40^{\circ} \mathrm{C}$ for a week. The dried extract thus obtained was used for assessment of anticancer activities. For methanolic extract methanol is used.

Stock solutions of all the samples were prepared in DMSO: $\sim 5 \mathrm{mg}$ $/ \mathrm{ml} \mathrm{w} / \mathrm{v}$ or $\mathrm{v} / \mathrm{v}$ as applicable for the samples were dissolved.

\section{Cell line characteristics}

Cell lines HL- 60; Tissue - Blood peripheral; Morphology Lymphoblast; Cell type - Acute promyelocytic leukemia; Growth Properties - Suspension; Split Ratio -A ratio of 1:2 to 1:6; Media supplement - Every 3 to 4 days.

\section{Cytotoxicity assay (MTT Assay)}

This assay measures the reduction of yellow 3-(4,5dimethythiazol2-yl)-2,5- diphenyltetrazolium bromide (MTT) by mitochondrial succinate dehydrogenase.MTT enters the cells and passes into the mitochondria where it is reduced to an insoluble, coloured (dark purple) formazan product. The cells are then solubilized with an organic solvent (isopropanol) and the released, solubilized formazan reagent is measured spectrophotometrically.96well plate, multi-channel pipette, cell lines, MEM medium, DMSO, Trypsin, DOX, WST dye are required as materials. According to the standard procedure, the used medium has removed from T-25 flask. The cells are trypsinized at 500 rpm for $5 \mathrm{~min}$ by adding $2 \mathrm{ml}$ of trypsin. The pallet is resuspended in $2 \mathrm{ml}$ completed media. Cells are diluted to 10,000 cells per $\mathrm{ml}$ and use complete media to dilute cells. 100ul of cells are added in to each well. The first two wells were taken as a blank, next two follow by DMSO.DOX is added to next two wells as a standard compound. Plant extracts are added to the next followed wells respectively and incubate for 48hours. WST dye is added to all wells. After 2hours incubation, OD at $490 \mathrm{~nm}$ is read using ELISA reader (Enspire, Perkin Elmer).

\section{Calculations}

$$
\text { MTT ASSAY \% viability }=\left(\frac{O D \text { of test material }}{O D \text { of control }}\right) \times 100
$$

$\%$ Inhibition $=100-(\%$ Viability $)$ 


\section{Results}

The extracts were obtained from leaves, bark fruit /seeds using water and methanol as solvents. The percentage yield varies in all the three plants in both the solvent systems with plant parts (Table 1). Among these, the leaves yielded higher extract in methanol, as well as seeds of $G$. farquhariana and M. fatua var. magnifica while the bark and fruits of $S$. indica resulted in higher yield in aqueous system.

The aqueous and methanolic extracts $(100 \mu \mathrm{g} / \mathrm{ml})$ were obtained from the plant samples and are used for anticancer studies using HL -60 cell lines. The results of cytotoxic assay are showed in Table 2. A maximum viability of $85.4 \%$ was observed with methanolic seed extract, while a minimum of $44.6 \%$ with aqueous leaf extract of Samadera indica. However, there is a good viability percentages with aqueous and methanolic extracts of plant parts used in the present investigation. So cytotoxicity was to the lesser extent with methanolic and aqueous extracts of all the three plant species.
Table I Per cent yield*of extracts in different parts of Samadera indica, M. fatua var. magnifica and $G$. farquhariana

\begin{tabular}{llll}
\hline \multirow{2}{*}{ Plant parts } & \multicolumn{3}{l}{ Solvent system } \\
\cline { 3 - 4 } & & Water (Aqueous) & Methanol \\
\hline \multirow{2}{*}{ Samadera indica } & Leaf & $04.8 \pm 0.56$ & $07.4 \pm 0.67$ \\
& Bark & $05.0 \pm 0.73$ & $02.82 \pm 0.088$ \\
\multirow{2}{*}{ M. fatua var. magnifica } & Fruit & $04.7 \pm 0.29$ & $02.15 \pm 0.155$ \\
& Leaf & $09.3 \pm 0.13$ & $15.22 \pm 0.087$ \\
G. farquhariana & Seed & $12.5 \pm 0.48$ & $50.0 \pm 0.36$ \\
& Leaf & $07.26 \pm 0.86$ & $16.3 \pm 0.33$ \\
& Seed & $11.3 \pm 0.94$ & $37.63 \pm 0.97$
\end{tabular}

*means of five replicates, mean \pm SE

Table 2 Results of cytotoxicity studies of aqueous and methanolic plant extracts with Cell line HL-60

\begin{tabular}{lll}
\hline Extracts & \% Viability & \% Inhibition* \\
\hline Aqueous seed extract of M. fatua var. magnifica & 63.3 & $36.7 \pm 1.38$ \\
Methanolic seed extract of M. fatua var. magnifica & 75.4 & $24.6 \pm 0.89$ \\
Methanolic seed extract of G. farquhariana & 65.6 & $34.4 \pm 1.21$ \\
Aqueous seed extract of G. farquhariana & 45.9 & $54.1 \pm 0.69$ \\
Methanolic leaf extract of M. fatua var. magnifica & 56.7 & $43.3 \pm 1.05$ \\
Aqueous leaf extract of M. fatua var. magnifica & 56.5 & $43.5 \pm 0.52$ \\
Methanolic leaf extract of G. farquhariana & 62.9 & $37.1 \pm 0.34$ \\
Aqueous leaf extract of G. farquhariana & 73.6 & $26.4 \pm 0.42$ \\
Aqueous leaf extract of Samadera indica & 85.4 & $14.6 \pm 0.70$ \\
Methanolic fruit extract of Samadera indica & 50.2 & $49.8 \pm 0.42$ \\
Methanolic bark extract of Samadera indica & 65.2 & $34.8 \pm 0.50$ \\
Aqueous leaf extract of Samadera indica & 44.6 & $55.4 \pm 0.23$ \\
Aqueous fruit extract of Samadera indica & 70.5 & $29.5 \pm 0.41$ \\
Aqueous bark extract of Samadera indica & 52 & $48.0 \pm 0.49$ \\
\hline
\end{tabular}

*average of 4 readings, mean $\pm S E$ (standard error) Concentrations used: $100 \mu g / \mathrm{ml}$

\section{Discussion}

The quantity of extracts varied in plant parts as well as among plant species. It also differs with solvent systems too. In the present study, methanol yielded better quantity compared with aqueous one which was comparable to earlier reports. The plant parts possessed varied level of secondary metabolites including phenolic compounds as reported in earlier works. ${ }^{12,13,15-17}$ According to Singh et al. ${ }^{18}$ phenolic compounds possess biological properties such as antiapoptosis, antiaging, anticarcinogen, antiinflammation, as well as inhibition of angiogenesis and cell proliferation activities. Phytosterol acts as growth hormones in plants. The plant has medicinal property due to the presence of these phytochemicals. ${ }^{19}$

In the present study aqueous and methanolic extracts of fruit, leaves, seed and bark of three plants were studied with HL - 60 cell lines, showed the greater extent of inhibition at a range of $14-55 \%$. Even though viability up to $85 \%$ in few extracts but was gradually reduced in others. All the leaf extracts clearly exhibited cytotoxicity activity through reduction in the viability and increased inhibition. $G$. farquhariana seed extract and $S$. indica fruit extract also showed inhibition to greater extent compared with $M$. fatua var. magnifica extracts. In one of the earlier study by Helen, ${ }^{20}$ it was found that, on adding essential oil of Myristica fragrans in various concentrations to the Michigan Cancer Foundation-7 (MCF-7) breast cancer cell line and A-357 epidermal skin cancer cell line, there was cytotoxic effect. The essential oil of nutmeg showed significant inhibition on the expansion of a colon cancer cell line (undifferentiated Caco-2 cells) in an in vitro study. ${ }^{21}$ The methanol extract of $M$. fragrans caused cell death of Jurkat leukemia $\mathrm{T}$ cell line by a mechanism involving SIRTI mRNA down regulation. ${ }^{22}$ It has been proved that $M$. fragrans inhibits the challenge growth microorganism using $20 \% \mathrm{v} / \mathrm{v}$ of the extract. ${ }^{23}$ The covering of the seeds of nutmeg has chemopreventive property. It significantly reduced the incidence of a skin papilloma in Swiss albino mice. ${ }^{24}$ The preventive action of nutmeg was studied on methylcholanthrene-induced carcinogenesis in the uterine cervix in Swiss albino mice. After a dose of $10 \mathrm{mg} /$ mouse/day for $90 \mathrm{~d}$ there was 
a significant decrease in the extent of carcinoma. ${ }^{25}$ Ethanolic extract of $M$. fragrans was used to test anti-cancer activity against human cancer cell lines and it showed more than $70 \%$ growth inhibition at a concentration of $100 \mu \mathrm{g} / \mathrm{ml} .{ }^{26}$ As in the present study which were tested with HL- 60 cell line showing good result compared with nutmeg extract, which is member of same family Myristicaceae. On the other hand, Chakraborty et al., ${ }^{14}$ studied the anticancer activity of methanol extract the Myristica fragrans against human osteosarcoma cell line (MG 63) and found in methanol extract cell viability is decreased with increased concentration of extract, which indicated the moderate activity of the extract. Likewise, $12.5 \mu \mathrm{g} / \mathrm{ml}$ concentration of extract showed less than $5 \%$ of cell inhibition while at $50 \mu \mathrm{g} / \mathrm{ml}$ concentration of extract, percentage of cell inhibition reaches $63 \%$, which indicated that percentage of cell inhibition is increased with increasing concentration of extract. The IC 50 value is calculated to be $40.39 \mu \mathrm{g} / \mathrm{ml}$ at which concentration the percentage of cell inhibition reaches 50 . The report further indicates the presence of anticancer activity of both methanol extract of $M$. fragrans. Will be extended even with other members of the same family.

The results of cytotoxicity of the selected plant samples (ethanol extract) against the selected cancer cells Rafik Shaikh et al., ${ }^{27}$ observed that the ethanol phytofraction $(1 \mathrm{mg} / \mathrm{ml})$ of all the tested plants showed promising anticancer activity toward the selected cancer cell lines. $L$. bipinnata possessed significant anticancer activity by inhibiting PN$15(35.21 \pm 1.48 \%)$, while $S$. fembrifuga showed moderate inhibition toward PN-15 (06.35 $\pm 0.35 \%)$. All the plants under investigation were found to possess moderate cytotoxic activity toward HeLa-B75 and HL-60 cell lines, showing the activity in the range of $12.14-34.21 \%$. The cytotoxic activity was compared with suramin $(0.01 \mathrm{mM})$, which was used as the standard anticancer drug (HeLa-B75, 91.55\%; HL-60, 72.51\%; HEP-3B, 92.43\%; and PN-15, 77.38\%). None of the plant samples showed cytotoxicity toward normal "Chang liver" cells, except the standard $\mathrm{H}_{2} \mathrm{O}_{2}(3.13 \%)$.

With regard to the management of cancers, ellagic acid and a whole range of flavonoids, carotenoids, and terpenoids present in Fragaria vesca (strawberries) and Rubus idaeus (raspberries) have been reported to be responsible for the antioxidant activity. These chemicals block various hormonal actions and metabolic pathways that are associated with the development of cancer. ${ }^{28,29} \mathrm{~A}$ whole variety of phenolic compounds, in addition to flavonoids, are widely distributed in grains, fruits, vegetables, and herbs. Phenolic compounds such as caffeic and ferulic acids, sesamol, and vanillin have been reported to exhibit antioxidant and anticarcinogenic activities and inhibit atherosclerosis. ${ }^{30-32}$

\section{Acknowledgements}

None.

\section{Conflict of interest}

The author declares no conflict of interest

\section{References}

1. Kelloff GJ. Perspectives on cancer chemoprevention research and drug development. Adv Cancer Res. 2008;78:199-334.

2. David A Warrell. Oxford Text Book of Medicine. 4th ed. India: Oxford University Press; 2003. p. 483-484.

3. Reddy L, Odhav B, Bhoola KD. Natural products for cancer prevention: a global perspective. Pharmacol Ther. 2003;99(1):1-13.
4. Babior BM. Phagocytes and oxidative stress. Am JMed. 2000;109(1):3344.

5. Nipun D, Vijay S, Jaykumar B, et al. Antitumor activity of Dendrophthoe falcata against Ehrlich Ascites Carcinoma in Swiss Albino Mice. Pharma Crops. 2011;2:1-7.

6. Fennell CW, Lindsey KL, McGaw LJ, et al. Assessing African medicinal plants for efficacy and safety: Pharmacological screening and toxicology. J Ethnopharmacol. 2004;94(2-3):205-217.

7. Dung NX, Loi DT. Selection of traditional medicines for study. $J$ Ethnopharmacol. 1991;32(1-3):57-70.

8. Prior R, Cao G. Antioxidant phytochemicals in fruits and vegetables Diet and health implications. Hort Sci. 2000;35(4):588-592.

9. Jayalakshmi CP, Sharma JD. Effect of butylated hydroxyanisole (BHA) and butylated hydroxytoluene (BHT) on rat erythrocytes. Environ Res. 1986;41(1):235-238.

10. Ignacimuthu S, Ayyanar M, Sivaraman SK, Ethnobotanical investigations among tribes in Madurai district of Tamil Nadu (India). J Ethnobiol Ethnomed. 2006;2:25.

11. Rama Bhat P, Kaveriappa KM. Ecological studies on Myristica swamp Forests of Uttara Kannada, Karnataka, India. Tropical Ecology. 2009;50(2):329-337.

12. Medha Tantry, Rama Bhat P. Phytochemical screening, antimicrobial and antioxidant activities of Myristica fatua Houtt. var. magnifica (Beddome) Sinclair. Palgo Journal of Medicine and Medical Science. 2016;3(4):97102.

13. Chaithanneya, Rama Bhat P. Studies on phytochemical properties, antimicrobial and antioxidant activities of seeds of Gymnacranthers farquhariana (Hook. f. \& Thomson) Warb. Biochemistry and Biotechnology Research. 2016;4(4):77-82.

14. Chakraborty P, Lavanya P, Abraham J. Bioactivity of Myristica fragrans methanol extract. World Journal of Pharmaceutical Research. 2015;4(9):1145-1157.

15. Edeoga OH, Okwu ED, Mbaebie OB. Phytochemical Constituents of Some Nigerian Medicinal Plants. Afr J Biotechnol. 2005;4(7):685-688.

16. Viswanad V, Aleykutty NA, Jaykar B, et al. Studies on antimicrobial and antioxidant activity of methanolic extract of Samadera indica. Int $J$ Pharmaceut Sci Rev Res. 2011;11(2):59-64.

17. Deepa PR, Chaithanneya, Rama Bhat P. Phytochemical properties and antimicrobial activities of leaf, bark, fruit extracts and silver nanoparticles of Samadera indica Gaertner. European J Biotechnol Biosci. 2015;3(12):30-37.

18. Thomas AR, Krishnakumari S. Phytochemical profiling of Myristica fragrans seed extract with different organic solvents. Asian Journal of Pharmaceutical and Clinical Research. 2015;8(1):303-307.

19. Singh R, Singh S, Kumar S, et al. Evaluation of antioxidant potential of ethyl acetate extract/fractions of Acacia auriculiformis A. Cunn. Food Chem Toxicol. 2007;45:1216-1223.

20. Dethe UL, Joshi SS, Desai SS, et al. Screening of bioactive compounds of Sesbania grandiflora and Pistia stratiotes. Indian Journal of Adv Plant Res. 2014;1(1):27-30.

21. Helen PM. Phytochemical analysis and anticancer activity of essential oil from Myristica fragrans. Int J Curr Pharm. 2012;2(4):188-198.

22. Piras A, Rosa A, Marongiu B. Extraction and separation of volatile and fixed oils from seeds of Myristica fragrans by supercritical $\mathrm{CO}_{2}$ :chemical composition and cytotoxic activity on Caco-2 cancer cells. J Food Sci. 2012;77(4):448-453 
23. Chirathaworn C, Kongcharoensuntorn W, Dechdoungchan T, et al Myristica fragrans houtt. methanolic extract induces apoptosis in a human leukemia cell line through SIRT1 mRNA down regulation. $J$ Med Assoc Thai. 2007;90(11):2422-2428.

24. Ejechi BO, Souzey JA, Akpomedaye DE. Microbial stability of mango (Mangifera indica L.) juice preserved by combined application of mild heat and extracts of two tropical spices. J Food Prot. 1998;61(6):725727.

25. Jannu LN, Hussain SP, Rao AR. Chemopreventive action of mace (Myristica fragrans, Houtt) on DMBA-induced papilloma genesis in the skin of mice. Cancer Lett. 1991;56(1):59-63.

26. Hussain SP, Rao AR. Chemopreventive action of mace (Myristica fragrans, Houtt) on methylcholanthrene-induced carcinogenesis in the uterine cervix in mice. Cancer Lett. 1991;56(3):231-234.

27. Prakash E, Gupta DK. Cytotoxic activity of ethanolic extract of Myristica fragrans (Houtt.) against seven human cancer cell lines. Universal $J$ Food Nutrition Sci. 2013;1(1):1-3.
28. Rafik Shaikh, Mahesh Pund, Ashwini Dawane, et al. Evaluation of Anticancer, Antioxidant, and Possible Anti-inflammatory Properties of Selected Medicinal Plants Used in Indian Traditional Medication. $J$ Tradit Complement Med. 2014;4(4):253-257.

29. Caragay AB. Cancer-preventative foods and ingredients. Food Technol. 1992;46:65-68.

30. Steinmetz KA, Potter JD. Vegetables, fruits and cancer, I. Epidemiology. Cancer Causes Control. 1991;2(5):325-357.

31. Decker EA. The role of phenolics, conjugated linoleic acid, carnosine, and pyrroloquinoline quinone as nonessential dietary antioxidants. Nutr Rev. 1995;53:49-58.

32. Craig WJ. Phytochemicals: Guardians of our Health. J Am Diet Assoc. 1997;97(10 Suppl 2):S199-S204. 